\title{
Environment type and storage period on eggshell quality of laying hens at different ages
}

\author{
Sarah Maria Pires Camargo ${ }^{1^{*}}$ (1) Natiele Ferraz de Oliveira ${ }^{1}$ (D) Deibity Alves Cordeiro ${ }^{1}$ (i) \\ Helder Freitas de Oliveira ${ }^{1}$ (D) Deborah Pereira Carvalho' (i) Carlos Henrique Rodrigues Rocha ${ }^{1}$ (i)

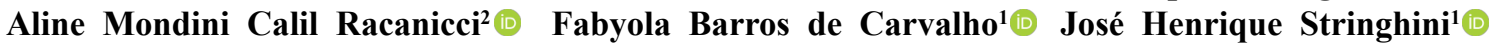

${ }^{1}$ Departamento de Zootecnia, Universidade Federal de Goiás (UFG), 74690-900, Goiânia, GO, Brasil. E-mail: sarahcamargo_@hotmail.com. ${ }^{*}$ Corresponding author.

${ }^{2}$ Faculdade de Agronomia e Medicina Veterinária, Universidade de Brasília (UNB), Brasília, DF, Brasil.

ABSTRACT: Eggshell quality is directly linked to the good acceptability of the product by consumers, whereas the industry is concerned with economic losses. Prolonged periods of laying, diseases, nutrition, bird age and genetics can influence egg quality. This study aimed to examine the influence of the environment, bird age and storage period on the physical characteristics of the shell of eggs from commercial laying hens. The experiment involved 288 eggs from $\mathrm{Hy}$-line hens, which were distributed in a completely randomized design with a triple $3 \times 2 \times 4$ factorial arrangement represented by three ages (31, 62 or 88 weeks), two storage temperatures (ambient or refrigerated), and four storage periods (one, 10, 20 or 30 days), totaling 24 treatments. Four replications were used with three eggs each. Eggshell strength, percentage and thickness were measured. Differences were observed, with the eggs stored at room temperature exhibiting lower shell strength. Laying eggs at an advanced age (88 weeks) resulted in decreased eggshell strength as compared with the other ages, whereas the eggs from young layers (31 weeks) had a thicker shell. The advancing age of the laying hens reduced eggshell quality, regardless of the storage environment. Nonetheless, the eggs stored in the refrigerator showed better eggshell quality and integrity than those stored at ambient temperature.

Key words: storage, ambient temperature, refrigeration, eggshell thickness, eggshell strength.

Tipos de ambiente e período de armazenamento sobre a qualidade de casca de ovos de poedeiras comerciais em diferentes idades

RESUMO: A qualidade da casca está diretamente ligada à boa aceitabilidade do produto pelos consumidores, enquanto a indústria se preocupa com as perdas econômicas. Periodos prolongados de postura, doenças, nutrição, idade da ave e genética podem influenciar a qualidade dos ovos. Objetivou-se avaliar a influência do ambiente, idade da ave e periodo de armazenamento nas características físicas da casca de ovos de poedeiras comerciais. Foram utilizados 288 ovos de poedeiras Hy-line, distribuídos em um delineamento inteiramente casualizado em fatorial triplo 3x2x4, sendo os fatores: três idades (31, 62 e 88 semanas), temperatura de armazenamento (ambiente e refrigerado), e quatro periodos de armazenamento (um, 10, 20 e 30 dias), totalizando 24 tratamentos, com quatro repetições de três ovos. Avaliou-se a resistência, percentual e espessura da casca. Foram observadas diferenças, uma vez que os ovos armazenados em temperatura ambiente apresentaram diminuição na resistência de casca. Ovos de poedeiras em idade avançada (88 semanas) apresentaram pior resistência de casca em relação às demais idades, enquanto ovos provenientes de poedeiras jovens (31 semanas) apresentaram maior espessura de casca. A idade avançada da poedeira reduziu a qualidade de casca dos ovos, independentemente do ambiente de armazenamento. Ainda, os ovos armazenados em geladeira apresentaram melhor qualidade e integridade da casca em comparação com os armazenados ao ambiente.

Palavras-chave: estocagem, temperatura ambiente, refrigeração, espessura de casca, resistência de casca.

\section{INTRODUCTION}

The eggshell is considered a natural packaging for the egg, consisting of organic and mineral substances that account for 8 to $11 \%$ of the total egg components. This structure is constituted by $94 \%$ calcium carbonate $\left(\mathrm{CaCO}_{3}\right), 1.4 \%$ magnesium carbonate
$\left(\mathrm{MgCO}_{3}\right)$ and 3\% glycoproteins, mucoproteins, collagen and mucopolysaccharides. The mineral portion is composed of $98.2 \%$ calcium carbonate, with calcium comprising around $4 \%$ of the egg weight (BARBOSA et al., 2011; VIEIRA et al., 2012).

The shell membrane, in turn, is formed by two layers: an outer thick layer called "spongy 
layer", close to the shell, and an inner thin one known as "mammillary layer". This structure provides resistance to the eggshell and protects the egg content. In young layers, the eggshell membranes are thicker and play an important role in its structure (BARBOSA et al., 2012).

Eggshells also have small pores (700017000) that allow gas exchange between the internal and external media of the egg, mostly oxygen influx and carbon dioxide outflux. These pores are covered by a cuticle made of wax that protects the egg from water loss and prevents the penetration of microorganisms (LACA et al., 2017).

In general, the quality of the eggshell is important for the product to be well-accepted by consumers. In this respect, some factors directly influence the quality of this structure, e.g., prolonged periods of laying, heat stress, diseases, nutritional deficiencies, bird age and genetics (VIEIRA et al., 2012). In addition, high temperatures accelerate the loss of carbon dioxide to the external environment, constituting poor preservation and causing loss of properties.

With the advance of laying age, there is a natural decline in eggshell quality, since there is an increase in egg size that coincides with a lesser ability to mobilize bone calcium to form the shell due to age. Coupled with this, several quality attributes are lost with the prolonged storage of the egg, depending on the temperature, humidity and the movement of carbon dioxide from the albumen to the shell (FIGUEIREDO et al., 2011; MENEZES et al., 2012; BARBOSA et al., 2012).

This study was undertaken to examine the influence of the environment, bird age and storage period on the physical characteristics of the shell of eggs from commercial laying hens.

\section{MATERIALS AND METHODS}

The experiment was carried out in the Poultry Section of the School of Veterinary and Animal Science at the Federal University of Goiás, Goiânia, Brazil (16³5’33.0” S, 49¹6'51.4” W).

A total of 288 eggs from commercial laying hens of the Hy-line line at 31, 62 or 88 weeks of age were used. The experiment was laid out in a completely randomized design with a triple $3 \times 2 \times 4$ factorial arrangement represented by three laying ages $(31,62$ or 88 weeks), two environments (ambient temperature or refrigerated) and four storage periods (one, 10, 20 or 30 days). Four replicates were used with three eggs each, totaling 24 treatments.
The following statistical model was used: $\mathrm{Y}_{\mathrm{ijkn}}=\mu+\alpha_{\mathrm{i}}+\beta_{\mathrm{j}}+\gamma_{\mathrm{k}}+(\alpha \beta)_{\mathrm{ij}}+\left(\alpha_{\gamma}\right)_{\mathrm{ik}}+(\beta \gamma)_{\mathrm{jk}}+\delta_{\mathrm{ijk}}+\varepsilon_{\mathrm{ijkn}}$, where $Y_{i \mathrm{ijk}}$ : response variable related to level $i$ of the first factor $(i=1,2, \ldots, a)$, with level $j$ of the second factor $(j=1,2, \ldots, b)$, with level $k$ of the third factor $(\mathrm{k}=1,2, \ldots, \mathrm{c})$ in replicate $\mathrm{n}(\mathrm{n}=1,2, \ldots, \mathrm{d})$; $\mu$ : overall mean; $\alpha_{i}$ : effect of level $\mathrm{j}$ of the first factor;

$\beta_{\mathrm{j}}$ : effect of level $\mathrm{j}$ of the second factor;

$\gamma_{k}$ : interaction effect between level $i$ of the first factor and level $\mathrm{j}$ of the second factor;

$(\alpha \beta)_{\mathrm{ij}}$ : interaction effect between factors 1 and 2 ;

$(\alpha \gamma)_{\mathrm{ik}}$ : interaction effect between factors 1 and 3;

$(\beta \gamma)_{\mathrm{jk}}$ : interaction effect between factors 2 and 3;

$\delta_{\mathrm{ijk}}$ : interaction effect between factors 1, 2 and 3;

$\varepsilon_{\mathrm{ijkn}}$ : experimental error associated with observation $\mathrm{Y}_{\mathrm{ijkn}}$, assumed $\varepsilon_{\mathrm{ijk}} \sim \mathrm{N}\left(0, \sigma^{2}\right)$ and independent.

The eggs were stored in previously identified commercial cardboard packaging and kept at ambient temperature or in a refrigerator. Air temperature and relative humidity were recorded once daily with a digital thermometer. The recorded temperatures under shelf storage (ambient) conditions were $25.2^{\circ} \mathrm{C}$ (mean minimum) and $29.7^{\circ} \mathrm{C}$ (mean maximum). In the refrigerated environment, the recorded temperatures were $4.6{ }^{\circ} \mathrm{C}$ (mean minimum) and $11.5^{\circ} \mathrm{C}$ (mean maximum). Humidity was stable in the refrigerated environment, averaging $82.3 \%$. In the natural environment, however, it fluctuated, with an average of $66.7 \%$.

Eggshell quality was analyzed in three eggs, which represented an experimental unit. The following variables were evaluated: strength, thickness and percentage of eggshell.

In each storage period (fresh eggs, 10, 20 and 30 days of storage), the three eggs were identified individually and weighed on a precision scale $( \pm 0.001 \mathrm{~g})$. Subsequently, they were subjected to a shell strength analysis by the low-speed pressing method, using a Digital Egg Quality Tester (Nabel ${ }^{\circledR}$ DET-6000), which measured the eggshell strength at breaking.

Then, the shells were washed under running water to remove excess albumen, and ovendried for $24 \mathrm{~h}$. Afterwards, the shells were weighed and thickness measurements were performed using a digital caliper ( $\mathrm{mm}$ ) at two points in their central-transverse area. The eggshell percentages were obtained by multiplying the ratio of specificcomponent weight to egg weight by 100 .

Mean data were evaluated by analysis of variance (ANOVA) and Tukey's test using the R computer package and adopting $\alpha=0.05$. 
RESULTS

On the 1 st day immediately after laying, the 31-week-old hens showed the highest eggshell percentages (Table 1) for the eggs kept on the shelf, with $18 \%$ and $12 \%$ higher results than those obtained by the 62 - and 88 -week-old layers, respectively. In the case of refrigerated eggs, on the 1st day, eggshell percentage in the group aged 31 weeks was the same as that of the 88 -week-old layers, but differed from that of the 62-week-old layers.

From the 20th day of storage, the eggs from layers aged 62 weeks that were stored on the shelf had a higher eggshell percentage than on the 1 st day, which was probably due to loss of water. In addition, the 88-week-old layers showed a decrease in eggshell percentage on the 10th day of storage, even in the refrigerated environment.

On the 1st day of storage, in the shelf environment, there was a difference in this variable between the ages of 62 and 88 weeks in comparison to 31 weeks: the eggs from laying hens at an advanced age were already laid lighter, regardless of the environment in which they were stored. However, when stored in the refrigerator, the eggs from layers aged 62 weeks exhibited a lower eggshell percentage on the 1 st and 20th days of storage, whereas those from 88-week-old layers showed a lower percentage on the 10th day of storage.

Eggshell strength (Table 2) changed in response to the interaction effect between age and the environment. In the eggs stored on the shelf, shell strength decreased as bird age was increased.
The hens aged 88 weeks had lower eggshell strength values than the other group ages. Refrigerated eggs from 88 -week-old hens exhibited a $6 \%$ higher shell strength than shelf-stored eggs from 88-week-old layers (3.69 vs. 3.91). Regarding only the eggs stored on the shelf, between the 31- and 88 -week-old hens, eggshell strength was $29 \%$ higher in the eggs from young layers (4.77 vs. 3.69).

When we compare the ages in relation to time, no statistical difference is observed for eggshell strength on the 10th, 20th or 30th days between the ages of 31 and 62 weeks. On the other hand, the hens aged 88 weeks showed the lowest results in all storage periods, with values ranging between 3.72 and 3.84, the last of which was also equal to that of the 62 -week-old layers on the first day of storage. The 88 -week-old layers produced eggs with shells that were $19 \%$ less strong than those of the $31-$ and 62 week-old layers.

Over time, there were differences between the factors, with the refrigerated eggs showing a greater shell strength (4.64) at 30 days of storage when compared with the eggs kept on the shelf (4.15).

There was a significant interaction effect $(\mathrm{p}=0.0303)$ between laying age, environment and storage period for eggshell thickness (Table 3).

On the 1st day immediately after laying, the eggs from the 31-week-old layers showed a thicker shell, regardless of the environment. Eggshell thickness in laying hens aged 31 weeks was $15 \%$ greater than in the 88-week-old group. On the 10th and 20th day, the layers aged 88 weeks showed lower shell thickness values in both environments, when

Table 1 - Shell percentage of eggs from laying hens of different ages, stored on the shelf or in a refrigerator up to 30 days.

\begin{tabular}{|c|c|c|c|c|c|}
\hline \multirow[t]{2}{*}{ Environment } & \multirow[t]{2}{*}{ Layer age (weeks) } & \multicolumn{4}{|c|}{---------------------------------Storage period (days)------------------------------ } \\
\hline & & 1 & 10 & 20 & 30 \\
\hline \multirow{3}{*}{ Shelf } & 31 & $10.66 \mathrm{aA} \alpha$ & $10.10 \mathrm{aA} \alpha$ & $10.05 \mathrm{aA} \alpha$ & $10.19 \mathrm{aA} \alpha$ \\
\hline & 62 & $8.73 \mathrm{bA} \beta$ & $9.50 \mathrm{aA} \alpha \beta$ & $9.77 \mathrm{aA} \alpha$ & $9.81 \mathrm{aA} \alpha$ \\
\hline & 88 & $9.45 \mathrm{bA} \alpha$ & $10.25 \mathrm{aA} \alpha$ & $10.01 \mathrm{aA} \alpha$ & $10.11 \mathrm{aA} \alpha$ \\
\hline \multirow{3}{*}{ Refrigerator } & 31 & $10.17 \mathrm{aA} \alpha$ & $10.30 \mathrm{aA} \alpha$ & $10.07 \mathrm{abA} \alpha$ & $10.30 \mathrm{aA} \alpha$ \\
\hline & 62 & $9.13 \mathrm{bA \alpha}$ & $9.60 \mathrm{abA} \alpha$ & $9.41 \mathrm{bA} \alpha$ & $9.46 \mathrm{aA} \alpha$ \\
\hline & 88 & 9.63abA $\alpha \beta$ & $9.08 \mathrm{bB} \beta$ & $10.39 \mathrm{aA} \alpha$ & $10.15 \mathrm{aA} \alpha$ \\
\hline
\end{tabular}

CV: $5.34 \%$

p-value: 0.0403

a, b, c, d - means followed by different lowercase letters in the column differ from each other regarding the age, by Tukey's test.

A, B, C, D - means followed by different uppercase letters in the column differ from each other regarding the environment, by Tukey's test.

$\alpha, \beta, \delta, \lambda$ - means followed by different Greek letters in the row differ from each other regarding the time, by Tukey's test. 
Table 2 - Shell strength (Kgf) of eggs from laying hens of different ages, stored on the shelf or in a refrigerator up to 30 days.

\begin{tabular}{l}
\hline Layer age (weeks) ${ }^{*}$ \\
\hline
\end{tabular}

* Means followed by different lowercase letters in the column and uppercase letters in the row differ from each other, by Tukey's test.

** Means followed by different lowercase letters in the row and uppercase letters in the column differ from each other, by Tukey's test.

compared with the other ages: 0.22 on the shelf and 0.18 in the refrigerator. On the 30th day, in the refrigerated environment, the 88 -week-old layers maintained the same shell thickness $(0.26)$ relative to the thickness data from the first day.

A statistical difference occurred when the environment was related to layer age and egg storage period. On the 10th and 20th days, the 88 -week-old layers showed low shell thickness values, even when the eggs were stored under refrigeration.

The average shell thickness of one-day eggs from 31-week-old layers was $0.37 \mathrm{~mm}$; from 62-week-old layers, $0.29 \mathrm{~mm}$; and from 88-week-old layers, $0.26 \mathrm{~mm}$. After 20 days, these mean values dropped to $0.24,0.17$ and $0.22 \mathrm{~mm}$, respectively, considering the eggs stored on the shelf. In both refrigerated and shelf conditions, results differed between the evaluated environments and ages.

\section{DISCUSSION}

Alterations in egg quality begin to take place immediately after laying, changing its physical properties. Factors such as laying age and storage conditions directly influence the quality of this food. BRANDÃO et al. (2014) investigated differences between eggshell abnormalities during storage under controlled conditions in two seasons (summer and winter) and found that quality decreased over time and that storage temperature and humidity were the main factors influencing these changes.

At present, laying hens are raised up to more than 100 weeks of life in conventional systems (cages). This represents a prolongation of their useful life, exhaustion and problems inherent to age and the processing of these eggs, such as breaking of the shell on the conveyor belt and during processing, causing damage to the farm and the industry.

With the advancing age of a bird, the external quality of its eggs tends to decrease. Due to physiology, eggs from layers aged over 80 weeks are larger. As such, these eggs have losses in shell strength and thickness, since there is similar - and, in some cases, even less - mobility of calcium by the bird for an increasingly large egg. This usually results in less calcium carbonate deposited per egg area.

The strength of an eggshell depends on its thickness and matrix organization. As the bird grows older, its eggshell quality decreases considerably, which implies greater chances of alterations in the product.

KEMPS et al. (2006) examined the characteristics of the eggshell membranes and their changes during the laying production period, between 33 and 78 weeks of age, and observed that the strength 
Table 3 - Shell thickness (mm) of eggs from laying hens of different ages, stored on a shelf or in a refrigerator up to 30 days.

\begin{tabular}{|c|c|c|c|c|c|}
\hline \multirow[t]{2}{*}{ Environment } & \multirow[t]{2}{*}{ Layer age (weeks) } & \multicolumn{4}{|c|}{--1 } \\
\hline & & 1 & 10 & 20 & 30 \\
\hline \multirow{3}{*}{ Shelf } & 31 & $0.37 \mathrm{aA} \alpha$ & $0.27 \mathrm{aA} \delta$ & $0.24 \mathrm{aA} \lambda$ & $0.31 \mathrm{aA} \beta$ \\
\hline & 62 & $0.29 \mathrm{bA} \alpha$ & $0.26 \mathrm{aA} \alpha$ & $0.17 \mathrm{bA} \beta$ & $0.29 \mathrm{abA} \alpha$ \\
\hline & 88 & $0.26 \mathrm{cA} \alpha$ & $0.22 \mathrm{bA} \beta$ & $0.22 \mathrm{aA} \beta$ & $0.27 \mathrm{bA} \alpha$ \\
\hline \multirow{3}{*}{ Refrigerator } & 31 & $0.33 \mathrm{aB} \alpha$ & $0.25 \mathrm{aA} \delta$ & $0.22 \mathrm{aA} \delta$ & $0.29 \mathrm{abA} \beta$ \\
\hline & 62 & $0.30 \mathrm{bA} \alpha$ & $0.23 \mathrm{aB} \beta$ & $0.19 \mathrm{bA} \delta$ & $0.27 \mathrm{aB} \alpha$ \\
\hline & 88 & $0.26 \mathrm{cA} \alpha$ & $0.18 \mathrm{bB} \beta$ & $0.18 \mathrm{bB} \beta$ & $0.26 \mathrm{aA} \alpha$ \\
\hline
\end{tabular}

CV: $7.27 \%$.

P-value: 0.0303 .

a, b, c, d - means followed by different lowercase letters in the column differ from each other regarding the age, by Tukey's test.

A, B, C, D - means followed by different uppercase letters in the column differ from each other regarding the environment, by Tukey's test.

$\alpha, \beta, \delta, \lambda$ - means followed by different Greek letters in the row differ from each other regarding the time, by Tukey's test.

of attachment to the calcified portion of the shell and breaking strength decreased as the birds grew older.

According to VILELA et al. (2016), the thinner shell in eggs from older birds is related to a lower activity of the carbonic anhydrase enzyme, which may or may not be associated with lower intestinal absorption of calcium, bone mobilization and lower retention rate of this mineral.

Considering the three factors (age, time and environment) on the 1st day, eggshell strength was lower in eggs stored on the shelf than in the refrigerated eggs. This can be explained by the dehydration occurring at high temperatures, which makes the shell brittle and more vulnerable to cracks and breaking. SCOTT \& SILVERSIDES (2000) stated that higher temperatures increase the speed of loss of internal and external quality, in a given storage time, due to the loss of $\mathrm{CO}_{2}$ and moisture. As observed in this study, under refrigeration, moisture was maintained efficiently and prolonged, providing a stronger shell in the eggs that were kept there on the 1 st day.

The reduction in eggshell quality stems from the increasing egg size, which in turn leads to a lesser deposition of calcium carbonate per unit area as well as decreased mobilization and absorption of calcium by the bird. The calcium requirement of whiteegg layers aged 24 to 40 weeks is $4.5 \%$, corresponding to $3.7 \mathrm{~g} / \mathrm{bird} /$ day of calcium and $306 \mathrm{mg} / \mathrm{bird} /$ day of phosphorus (VELLASCO et al., 2016). Layers are able to adjust their calcium and phosphorus intake necessary for eggshell formation according to their needs. However, for birds at advanced ages, further studies on the real requirements of these minerals with advancing age, as well as supplementation, may be necessary to prevent losses in eggshell thickness and, consequently, strength.

One of the additional factors that influence eggshell quality is refrigeration. Ideally, eggs should be refrigerated from the farm to the table, even in commercial establishments, since refrigeration not only preserves the external quality, but reduces bacterial growth and prevents internal deterioration of the egg (MENDES et al., 2014).

To achieve savings in feed composition and increase shell breaking resistance, it is important to analyze the effectiveness of cost/benefit in increasing the longevity of laying hens as well as to seek improvements in the genetics of these animals, especially regarding the use and mobilization of calcium with advancing age. Eggshell strength is an important factor to be considered when handling eggs for consumption. Likewise, alternatives must be sought that provide a refrigerated environment for eggs in markets and the like, yet indirectly, so as not to substantially increase the final value of the product, since a refrigerated environment is proven to increase the longevity of products on the shelf, maintaining its physicochemical qualities. This is corroborated by LANA et al. (2017), who stated that refrigerated eggs maintain excellent quality standards up to 30 days.

\section{CONCLUSION}

Refrigerated eggs showed superior external quality to those stored on the shelf for 30 days. Eggshell strength and thickness were preserved in eggs stored up to 10 days, regardless of environment

Ciência Rural, v.52, n.1, 2021. 
type. After this period, storage time contributed to the process of deterioration of the eggshell characteristics and evidenced intrinsic problems of thin, fragile and brittle shells of eggs from old laying hens, influencing external egg quality. However, by refrigerating these eggs, the effects of storage were minimized.

\section{ACKNOWLEDGMENTS}

This study was financed in part by the Coordenação de Aperfeiçoamento de Pessoal de Nível Superior - Brasil (CAPES) - Finance Code 001.

\section{BIOETHICS AND BIOSSECURITY COMMITTEE APPROVAL} this manuscript

No animals were used to obtain the data and compose

\section{DECLARATION OF CONFLICT OF INTEREST}

We have no conflict of interest to declare with respect to the research, authorship and/or publication of this article.

\section{AUTHORS' CONTRIBUTIONS}

The authors also contributed equally to the manuscript.

\section{REFERENCES}

BARBOSA, V. C. et al. Stability of the pigmentation of egg yolks enriched with omega-3 and carophyll stored at room temperature and under refrigeration. Revista Brasileira de Zootecnia, v.40, n.7, p.1540-1544, 2011. Available from: <http://dx.doi. org/10.1590/S1516-35982011000700020>. Accessed: Mar. 1, 2020. doi: 10.1590/S1516-35982011000700020.

BARBOSA, V. M. et al. Evaluation of eggshell quality from broiler breeder hens with different ages. Arquivo Brasileiro de Medicina Veterinária e Zootecnia, v.64, n.4, p.1036-1044, 2012. Available from: <http://dx.doi.org/10.1590/S0102-09352012000400033>. Accessed: Mar. 1, 2020. doi: 10.1590/S0102-09352012000400033.

BRANDÃO, M. D. M. et al. The effect of eggshell Apex abnormalities on table egg quality during storage in 2 seasons of the year. Poultry Science, v.93, n.10, p.2657-2662, 2014. Available from: <https://doi.org/10.3382/ps.2014-03991>. Accessed: Mar. 1, 2020. doi: 10.3382/os.2014-03991.

FIGUEIREDO, T. C. et al. Quality of commercial eggs submitted to different storage conditions. Arquivo Brasileiro de Medicina
Veterinária e Zootecnia, v.63, n.3, p.712-720, 2011. Available from: <http://dx.doi.org/10.1590/S0102-09352011000300024>. Accessed: Mar. 1, 2020. doi: 10.1590/S0102-09352011000300024.

LACA, A. et al. Eggshell waste as catalyst: a review. Journal of Environmental Management, v.197, n.0, p.351359, 2017. Available from: <http://dx.doi.org/10.1016/j. jenvman.2017.03.088>. Accessed: Mar. 1, 2020. doi: 10.1016/j. jenvman.2017.03.088.

LANA, S. R. V. et al. Quality of eggs from commercial laying hens stored in different periods of temperature and storage. Revista Brasileira de Saúde e Produção Animal, v.18, n.1, p.140151, 2017. Available from: <http://dx.doi.org/10.1590/S151999402017000100013>. Accessed: Mar. 1, 2020. doi: 10.1590/ S1519-99402017000100013.

MENDES, F. R. et al. Bacteriological quality of washed and unwashed eggs stored under room temperature and refrigeration and contaminated with Pseudomonas aeruginosa. Ciência Animal Brasileira, v.15, n.4, p.444-450, 2014. Available from: <https:// doi.org/10.1590/1089-6891v15i431244>. Accessed: Mar. 1, 2020. doi: 10.1590/1089-6891v15i431244.

MENEZES, P. C. et al. Egg quality of laying hens in different conditions of storage, ages and housing densities. Revista Brasileira de Zootecnia, v.41, n.9, p.2064-2069, 2012. Available from: <http://dx.doi.org/10.1590/S1516-35982012000900014>. Accessed: Mar. 1, 2020. doi: 10.1590/S1516-35982012000900014.

SCOTT, T. A.; SILVERSIDES, F. G. The effect of storage and strain of hen on egg quality. Poultry Science, v.79, n.12, p.1725-1729 dec. 2000. Available from: <https://doi.org/10.1093/ps/79.12.1725>. Accessed: Mar. 2, 2021. doi: 10.1093/ps/79.12.1725.

VELLASCO, C. R. et al. Níveis de cálcio e relação cálcio: fósforo em rações para poedeiras leves de 24 a 40 semanas de idade. Ciência Animal Brasileira, v.17, n.2, p.206-216 abr./ jun. 2016. Available from: <http://dx.doi.org/10.1590/10896891v17i226916>. Accessed: Aug. 17, 2020. doi: 10.1590/1089$6891 \mathrm{v} 17 \mathrm{i} 226916$.

VIEIRA, D. V. G. et al. Levels of calcium and calcium: phosphorus ratio in diets for laiyng hens aged 24 to 40 weeks. Revista Brasileira de Saúde e Produção Animal, v.13, n.1, p.204-213, 2012. Available from: <https://doi.org/10.1590/S151999402012000100018>. Accessed: Mar. 1, 2020. doi: 10.1590/ S1519-99402012000100018.

KEMPS, B. J. et al. The influence of line ad laying period on the relationship between different eggshell and membrane strength parameters. Poultry Science, v.85, p.1309-1317, 2006.

VILELA, D. R. et al. Internal and external quality of commercial laying hens eggs with normal and vitreous eggshell. Ciência Animal Brasileira, v.17, n.4, p.509-518, 2016. Available from: $<$ http://dx.doi.org/10.1590/1089-6891v17i421535>. Accessed: Mar. 1, 2020. doi: 10.1590/1089-6891v17i421535. 